INSIGHTS INTO REGIONAL DEVELOPMENT

ISSN 2669-0195 (online) http://jssidoi.org/IRD/ 2020 Volume 2 Number 3 (September)

http://doi.org/10.9770/IRD.2020.2.3(6)

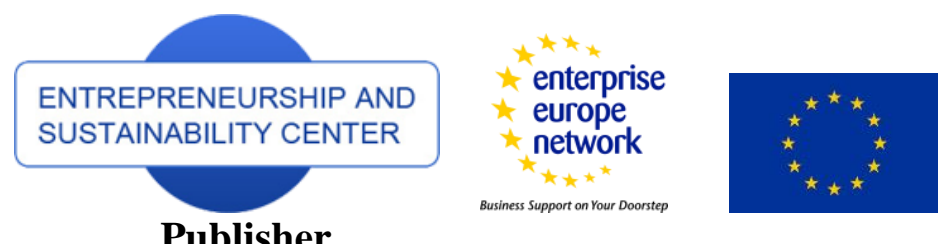

http://jssidoi.org/esc/home

\title{
DEVELOPMENT OF THE RADIO MARKET IN THE SLOVAK REPUBLIC IN THE YEARS 2016 TO 2019*
}

\author{
Marcel Lincenyi ${ }^{1}$, Fabus Michal ${ }^{2}$ \\ 1,2 Department of Economics and Finance, Economics and Management Institute, School of Economics and Management of \\ Public Administration in Bratislava, The Slovak Republic \\ E-mails: ${ }^{1}$ marcel.lincenyi@vsemvs.sk; ${ }^{2}$ michal.fabus@vsemvs.sk
}

Received 15 March 2020; accepted 15 July 2020; published 30 September 2020

\begin{abstract}
The paper is a part of a long-term research of the mass media market in the Slovak Republic under the conditions of globalization. The main objective of the research study is to analyse the development trends of the market of selected radios in the Slovak republic in the monitored period 2016-2019. The authors focus on the analysis of the development of listening and the volume of financial resources spent on advertising (number of spots, number of broadcast hours, value of advertising broadcasts) for selected radios with nationwide coverage. Among other things, the research showed a decrease in market share for all monitored radios and a decrease in listening for most of the monitored radios. The authors think that the above is because radio managements are not able to adapt sufficiently to the time that affects the listeners. From the above, the authors also warn the management of radio stations to increase the emphasis on development, the structure of broadcasting and to try to stop the clear decline in the development of radio.
\end{abstract}

Keywords: radio stations; broadcast; market development; market of radio stations; analysis, advertising amount

Reference to this paper should be made as follows: Lincenyi, M., Michal, F. 2020. Development of the radio market in the Slovak Republic in the years 2016 to 2019. Insights into Regional Development, 2(3), 689-702. https://doi.org/10.9770/IRD.2020.2.3(6)

JEL Classifications: M21, Y80

\footnotetext{
* The paper is the output of a scientific project IGA no. 3/2017 „Development of international business and international management in the conditions of globalization" (Funder: VSEMvs IGA VSEMvs, i.e. School of Economics and Management in Public Administration)
} 


\section{ENTREPRENEURSHIP AND SUSTAINABILITY ISSUES}

ISSN 2345-0282 (online) http://jssidoi.org/jesi/

2020 Volume 2 Number 3 (September)

http://doi.org/10.9770/IRD.2020.2.3(6)

\section{Introduction}

The size of the radio market can be analyzed by examining two basic variables: the audience of radios and the evolution of the volume of radio advertising placed in a broadcast. „Audience share is in media industry research, the percentage of all households tuned to a particular radio station/TV channel or programme at a particular time. A programme's share is affected factors such as competing." Chandler, Munday, 2011, p. 25) As he states (Burton, Jirák, 2001, p. 322), "an advertiser is usually interested in the viewership data, which tells how many people are watching the station at the time his ad is broadcast." Advertising attractiveness is something he does "a product that is particularly attractive or interesting to the recipients of the advertising message." (Světlík, Bulanda, 2019, p. 324)

\section{Methodology}

The main objective of the presented research study was to analyse the development trends of the selected Slovak proadcasters in the monitored period 2016-2019.

The secondary research goal of the research part was to analyse of listening and the volume of financial resources spent for advertising for selected radios in the Slovak republic with nationwide coverage. The market share of radios and the number of listeners, together with radio coverage, is and important parameter for the advertiser.

The contribution in the research context follows to the analysis of the development trends of the radio market in the Slovak Republic in the years 2011 to 2015, which showed, among other things, that the radio market was more or less stable, while the order of radio stations did not change at the highest ranks. Although there were smaller deviations in the recalculation of the market share of radios, either in decrease or increase, the order of these radios did not change in a single year. (Fabuš, Lincényi, 2018, p. 591)

In the case of further planning and research, we identified one main research question (VO), which we have developed into three more specific research questions.

The main research question: What were the development tendencies of the market of selected radios in the Slovak republic with nationwide operation in the observed period in the year 2016 to 2019?

Specific question n. 1: What is the development of listening to selected radios in the Slovak republic with nationwide coverage in the period from 2016 to 2019 ?

Specific question n. 2: What was the development of the volume of advertising in selected nationwide radios in the years 2016 to 2019 ?

Research material: In the Slovak Republic there are dozens of radio stations and radios: public, multiregional (broadcast nationwide), regional (broadcast in one or more) and local radio stations (broadcast only in one city), internet (broadcast only via the Internet), student internet radios. Due to the extensive research file, we decided to focus on the 5 most popular 5 Slovak radio stations: Radio Expres, Radio Slovakia, Radio Fun, Europa 2 radio and Fine radio.

We used several research methods to examine research goals and research questions. We processed data on listening and market share from the results of the national MML-TGI survey of MEDIAN SK. We analysed the volume of radio advertising (number of spots, number of hours, value of advertising broadcasts) on the basis of the results of Kantar Slovakia, Ltd. We further evaluated the data using statistical methods (statistical average, time series analysis) as well as a comparative method. 


\section{Result and Discussion}

\section{Radio market analysis in $\mathbf{2 0 1 6}$}

In the first annual follow-up in the wave 1+2/2016, Radio Slovensko listened to 794983 listeners, in second half of 2016, listening listened to 777112 listeners. On an annual average, the number of listeners is 786048 and market share was $21,65 \%$, the most so far in the period analysed by us.

Radio Expres also got worse, when 869370 listeners listened to the radio in the wave $1+2 / 2016$ and in the period $3+4 / 2016$ their number dropped to 865969 . This year the radio listened to an average of 867669 listeners and its market share was $22,76 \%$.

Fun radio also recorded a decrease compared to last year, when 497,008 listeners listened to it in the wave $1+$ 2/2016 and even less in the period $3+4 / 2016$, namely 491 738. The annual average of listeners was 494373 and the total market share of the radio was $12.45 \%$.

Radio Europe 2 maintained its market position with 326,657 listeners in the first half of the year, and there were fewer 320,170 in the $3+4 / 2016$ wave. After averaging the radio in 2014, 323,413 people listened, and its market share remained the same as last year at $7.95 \%$. Slightly lower market share compared to last year was achieved by Radio Jemné with 343,136 listeners for the wave $1+2 / 2016$ and in the wave $3+4 / 2016$ the listening listened to 328,431 listeners. As the radio listened to an average of 335,783 listeners, its share of the radio market was $7.94 \%$. The volume of listening to other radios that they broadcast in the monitored year was a total of $27.25 \%$. For more see Fig 1.

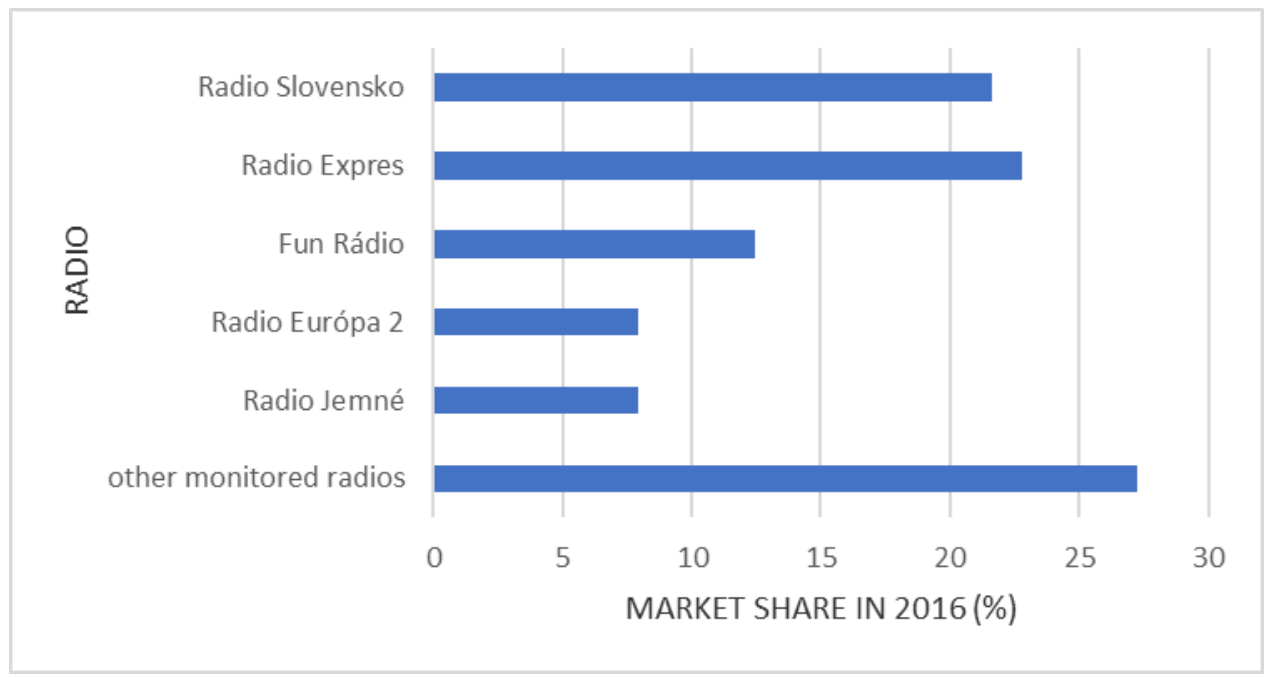

Fig. 1. Market share in 2016

Source: Processed form the results of the MML-TGI National Survey of MEDIAN SK

The media advertising market continued to grow in 2016, when total advertising spending in Slovakia, according to Kantar, reached $€ 1,358,970,300$, an increase of $6.02 \%$ over the previous year $(€ 1,277,139,448)$. $€ 83,908,907$ was invested in advertising space via radios in Slovakia, and a total of 1,910 hours of advertising were broadcast. Radio Slovensko recorded an increase in the number of spots $(27,751)$ and the total number of hours $(200)$, but on the contrary a decrease in the value of advertising broadcasts $(7,912,742)$, which is a decrease of $11.57 \%$ compared to the previous year. 
In 2016, Radio Expres broadcasted more spots than in the previous year $(53,210)$ in a smaller number of hours (328), for which it recorded an amount of $€ 28,745,377$, which is a decrease of $1.58 \%$ compared to the previous year.

Fun radio broadcasted fewer commercials (57,013), with fewer hours (370), while the value of its commercials in 2016 was $€ 21,943,687$, which is less than in the previous year.

Radio Europe 2 broadcast more commercials $(36,078)$ with more hours $(246)$ and its advertising space was valued at $€ 7,094,872$ this year. This was a record increase of $20.6 \%$ in recent years for this radio and also the highest increase for all radios in that year.

After a dramatic increase last year, radio Jemné recorded a drop in 54,124 broadcast spots in 2016 with a total of 367 hours of advertising and a value of advertising broadcasts of $€ 11,795,132$, which is a decrease of $8.79 \%$. For more see Fig.2.

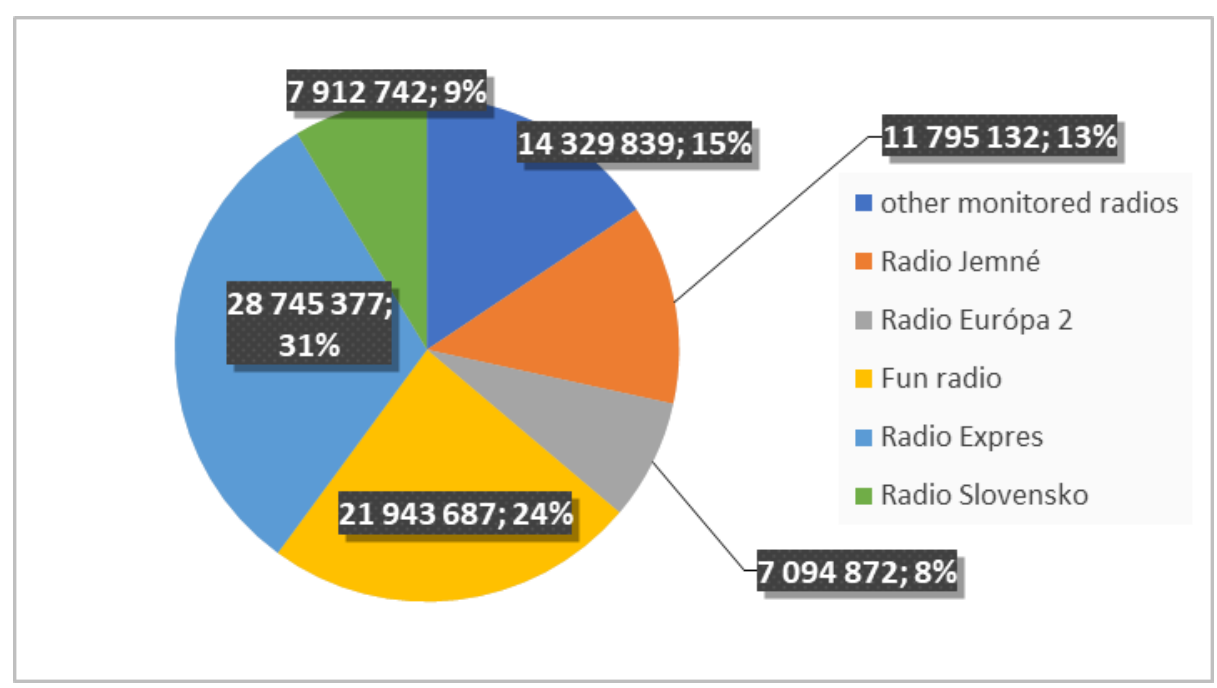

Fig. 2. Share of radio volume in the year 2016

Source: Processed form the results of Kantar Slovakia Ltd.

\section{Radio market analysis in 2017}

In the first annual follow-up in the wave $1+2 / 2017$, Radio Slovensko dropped to 757,498 listeners, in the second half of 2017, listening listened to 768,012 listeners. On an annual average, the number of listeners is 762,755 and the market share was $21.375 \%$.

Radio Expres also got worse, when 858,144 listeners listened to the radio in the wave of $1+2 / 2017$ and in the period $3+4 / 2016$ their number dropped slightly to 857,321 . This year the radio listened to an average of 857,732 listeners and $22.615 \%$.

Fun Radio also recorded a decrease compared to last year, when 496,081 listeners listened to it in the wave $1+$ $2 / 2017$ and even less in the period $3+4 / 2017$, namely 489,935. The annual average of listeners was 493,008 and the total market share of the radio was $12.815 \%$. 
Compared to last year, Radio Europe 2 also recorded a decrease in listening list, with 311,044 listeners in the first half of the year, and slightly more in the $3+4 / 2017$ wave $-312,159$. After averaging the radio in $2017,311,601$ people listened, and its market share fell to $7.62 \%$ compared to last year.

Slightly lower market share compared to last year was achieved by Radio Jemné with 325,609 listeners for the wave $1+2 / 2017$ and in the wave $3+4 / 2016$ the audience dropped to 324,210 listeners. As the radio listened to an average of 324,909 listeners, its share of the radio market was $7.625 \%$.

The volume of listening to other radios that they broadcast in the monitored year was a total of $27.95 \%$. For more see Fig. 3.

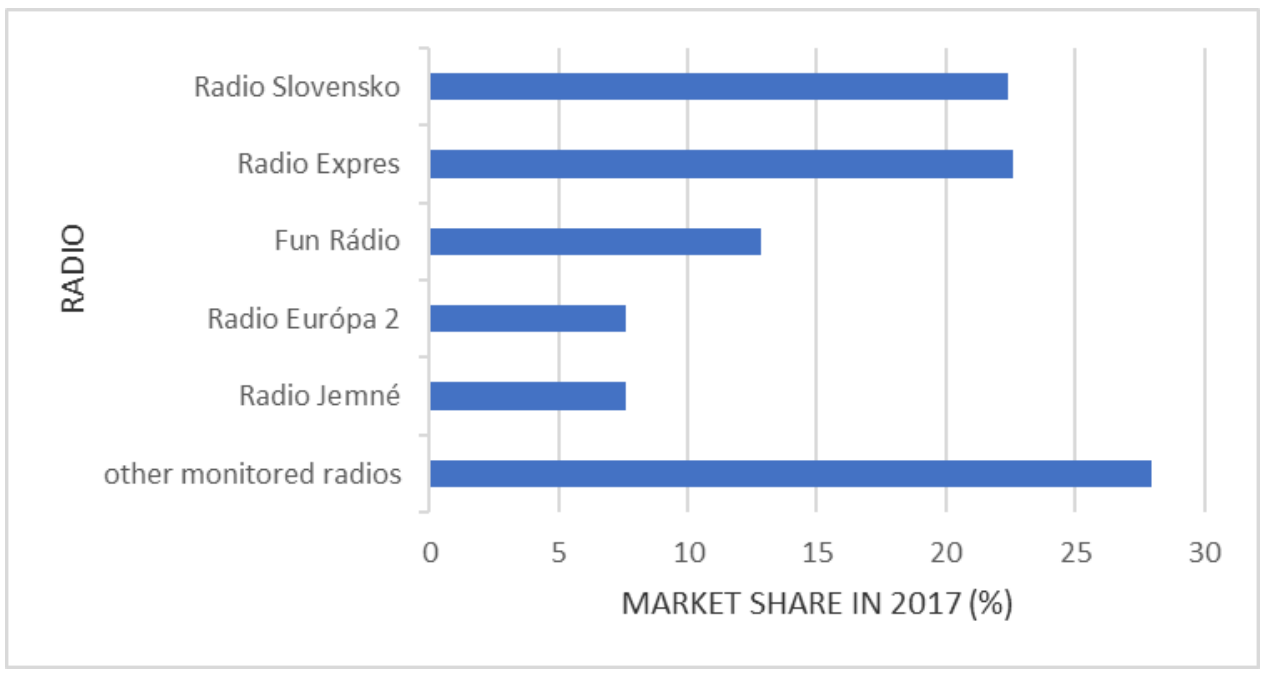

Fig. 3. Market share in 2017

Source: Processed form the results of the MML-TGI National Survey of MEDIAN SK

The media advertising market also grew in 2017, when total advertising spending in Slovakia, according to Kantar, amounted to $€ 1,609,201,169$, which is an increase of $15.55 \%$ compared to the previous year ( $€$ $1,358,970,300)$. In 2017, $€ 88,445,044$ was invested in advertising space on radios in Slovakia, and a total of 1,912 hours of advertising were broadcast.

Radio Slovensko recorded a decrease in the number of spots $(26,800)$ and the total number of hours (187), but on the contrary a decrease in the value of advertising broadcasts $(7,601,193)$, which is a decrease of $3.94 \%$ compared to the previous year.

In 2017, Radio Expres broadcast more spots $(56,456)$ in a larger number of hours $(355)$, for which it recorded an amount of $€ 31,152,265$, which is an increase of $7.72 \%$ compared to the previous year.

Fun radio broadcasted more commercials $(57,750)$, with fewer hours $(344)$, while the value of its commercials in 2017 was $€ 22,189,335$, which is more than in the previous year.

Europe 2 broadcasted significantly more commercials $(46,203)$ with more hours (304) and its advertising space was valued at $€ 9,278,743$ this year, which is another record increase of $23.54 \%$ in recent years for this radio and at the same time also the highest increase for all radios in a given year. 
Radio Jemné continued the decline in broadcast spots $(50,167)$ with a total of 339 hours of advertising and the value of advertising broadcasts of $€ 10,731,149$, which is a decrease of 9.02\%. For more see Fig. 4.

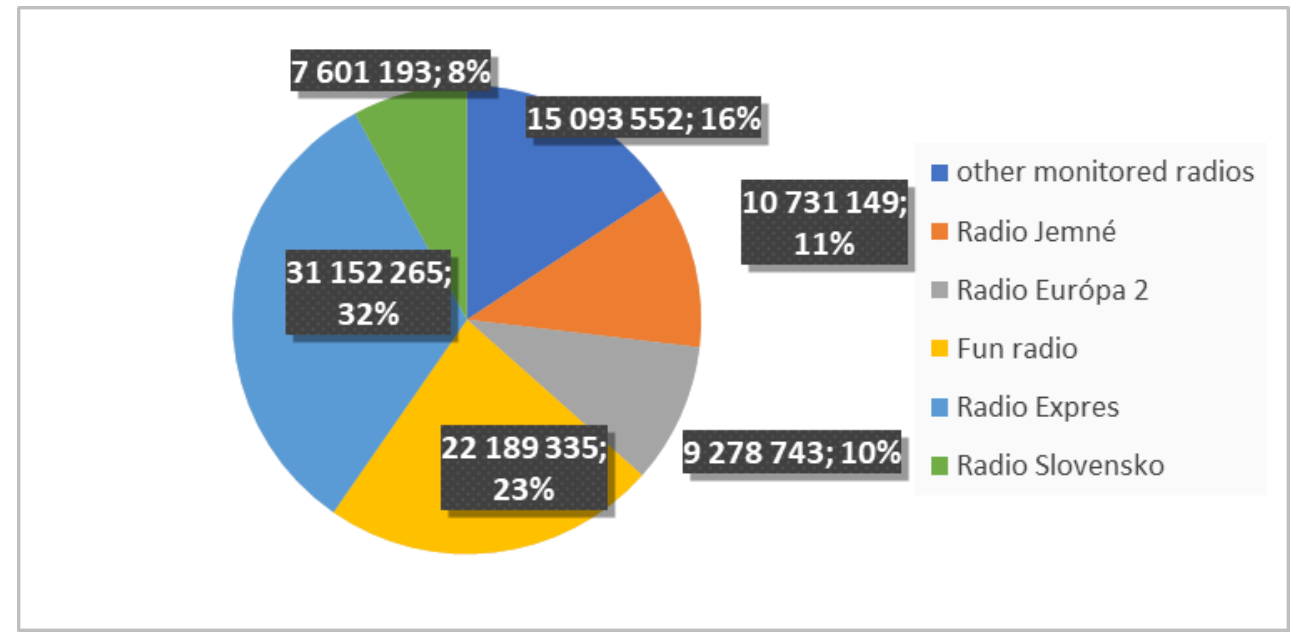

Fig. 4. Share of radio volume in the year 2017

Source: Processed form the results of Kantar Slovakia Ltd.

\section{Radio market analysis in 2018}

In the first annual follow-up in the wave $1+2 / 2018$, Radio Slovensko dropped slightly to 756,145 listeners, in the second half of 2018, listening listened to 737,642 listeners (on average 746,893 listeners). In 2018, data on the market share of radios for the $1+2 / 2018$ wave are not available, therefore for all radios we only present data for the $3+4 / 2018$ wave. Radio Slovakia achieved a market share of $22.08 \%$.

Radio Expres also got worse, with 838,761 listeners listening to the radio in the $1+2 / 2018$ wave, and in the $3+$ 4/2018 period their number dropped slightly to 828,576 (an average of 833,668 listeners). Radio Expres achieved a market share of $22.44 \%$ this year.

Fun radio also recorded a decrease compared to last year, when 488,467 listeners listened to it in the $1+2 / 2018$ wave and even less in the $3+4 / 2018$ period, namely 473,611 (on average 481,039 listeners). In 2018, Fun radio achieved an annual market share of $12.82 \%$.

Compared to last year, Radio Europe 2 recorded an increase in listening with 329,017 listeners in the first half of the year, in the $3+4 / 2017$ wave there were slightly more - 326,332 (on average 327,674 listeners). In Europe, Radio Europe 2 achieved a share of $8.26 \%$.

Slightly lower market share compared to last year was achieved by radio Jemné with 323,482 listeners for the wave $1+2 / 2018$ and in the wave $3+4 / 2018$ listening listened to 315,792 listeners (on average 319,637 listeners). Radio Jemné achieved a share of $7.11 \%$ this year.

The volume of listening to other radios that they broadcast in the monitored year was a total of $27.29 \%$. For more see Fig. 5. 


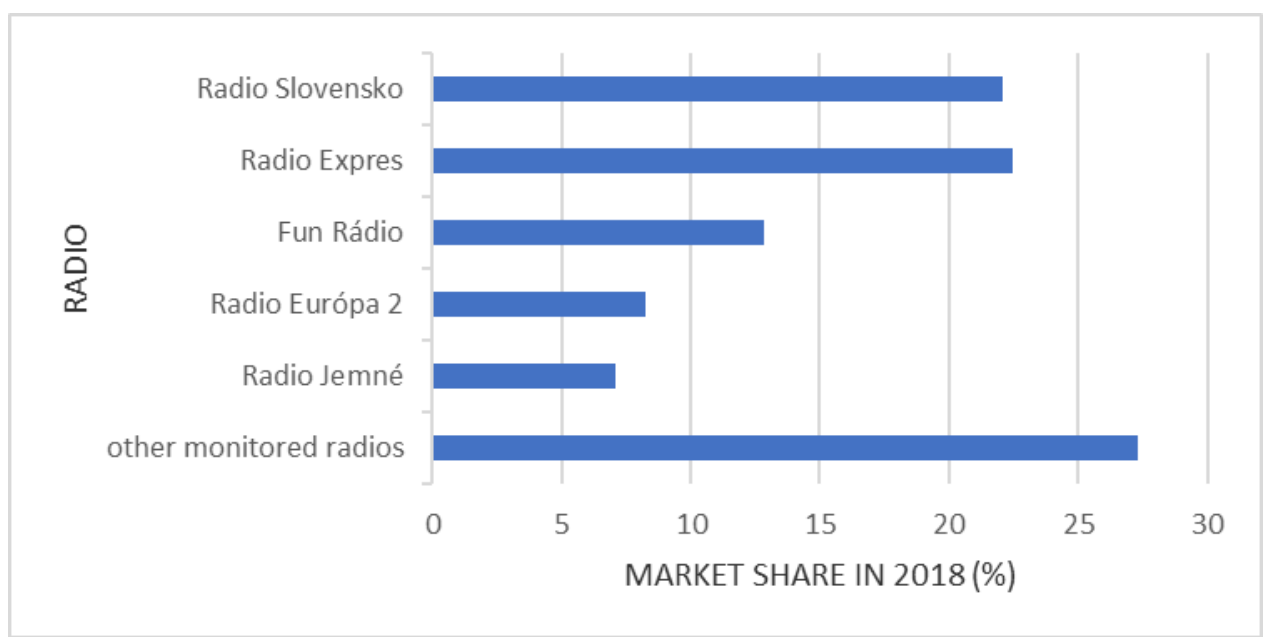

Fig. 5. Market share in 2018

Source: Processed form the results of the MML-TGI National Survey of MEDIAN SK

The media advertising market grew at a record high in 2018, when total advertising spending in Slovakia, according to Kantar, reached $€ 2,261,565,020$, an increase of $39.910 \%$ over the previous year $(€ 1,358,970,300)$. $€$ $91,855,095$ was invested in advertising space via radios in Slovakia, and a total of 2002 hours of advertising were broadcast.

Radio Slovensko recorded a decrease in the number of spots $(25,503)$ and a decrease in the total number of hours (169), but on the contrary an increase in the value of advertising broadcasts $(7,755,034)$, which is an increase of $1.98 \%$ compared to the previous year.

In 2018, radio Expres broadcast fewer spots $(54,410)$ in a smaller number of hours (343), for which it recorded an amount of $€ 30,179,111$, which is a decrease of $3.22 \%$ compared to the previous year.

Fun radio also broadcast fewer commercials $(56,720)$, with fewer hours (320), while the value of its commercials in 2018 was $€ 22,593,661$, which is more than in the previous year.

Radio Europe 2 broadcast significantly more commercials (52,541) with more hours (354) and its advertising space was valued at $€ 10,683,332$ this year, which is an increase compared to last year.

Radio Jemné broadcast more spots $(55,490)$ with a total number of 385 hours of advertising and a value of advertising broadcasts of $€ 12,223,814$, which is an increase of $12.21 \%$. For more see Fig. 6. 


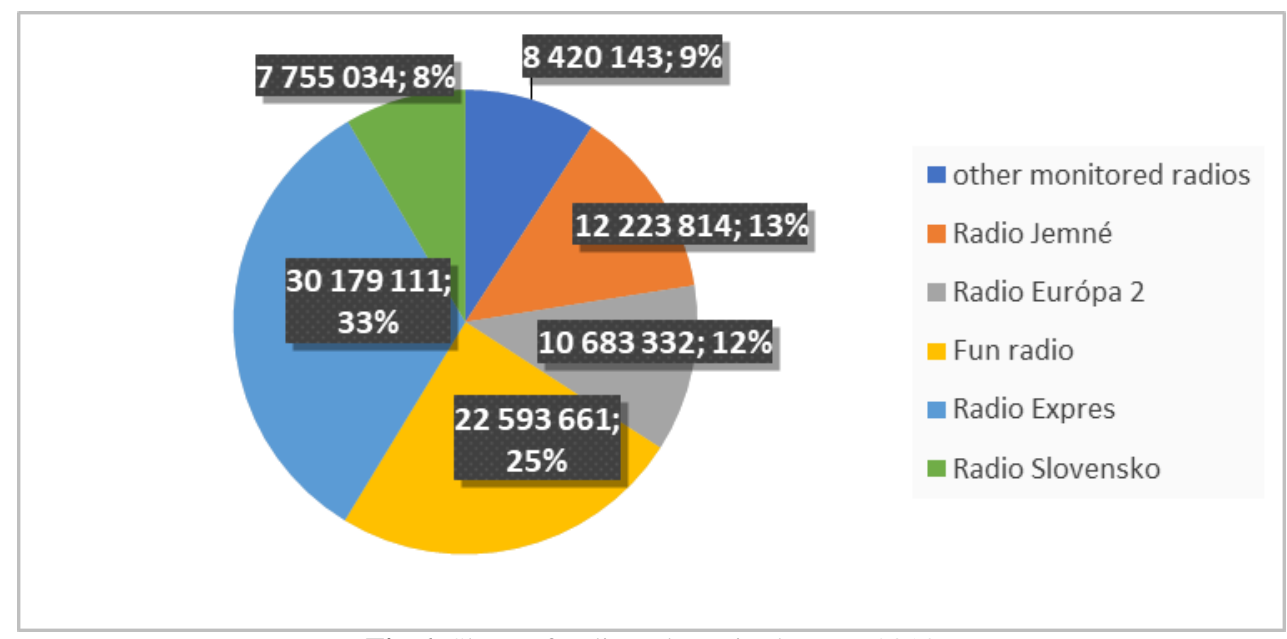

Fig.6. Share of radio volume in the year 2018

Source: Processed form the results of Kantar Slovakia Ltd.

\section{Radio market analysis in 2019}

In the first annual follow-up in the wave $1+2 / 2019$ Radio Slovensko dropped to 729,165 listeners, in the second half of 2019 the listenership dropped to 704,174 listeners. On an annual average, the number of listeners is 716.669 and the market share was $20.685 \%$.

Radio Expres also got worse, when the radio listened to 810081 listeners in the wave $1+2 / 2019$ and in the period $3+4 / 2019$ their number dropped slightly to 800263 . Radio this year listened to an average of 805,172 listeners and its market share was $22.02 \%$.

Fun radio recorded a slight increase compared to the previous year, when 448,745 listeners listened to it in the wave $1+2 / 2019$ and slightly less in the period $3+4 / 2019$, namely 441705 . The annual average of listeners was 445.225 and the total market share of radio was $12.22 \%$.

Compared to last year, Radio Europe 2 recorded a decrease in listening with the number of listeners in the first half of the year at 318,810, in the wave $3+4 / 2019$ there were slightly more of them $-322,535$. the market fell compared to last year to $7.005 \%$.

Radio Jemné achieved a lower market share compared to last year with 302,008 listeners for the $1+2 / 2019$ wave and in the $3+4 / 2019$ wave, listening listened to 293,271 listeners. As the radio listened to an average of 297,639 listeners, its share of the radio market was $6.69 \%$.

The volume of listening to other radios that they broadcast in the monitored year was a total of $20.11 \%$. For more see Fig. 7. 


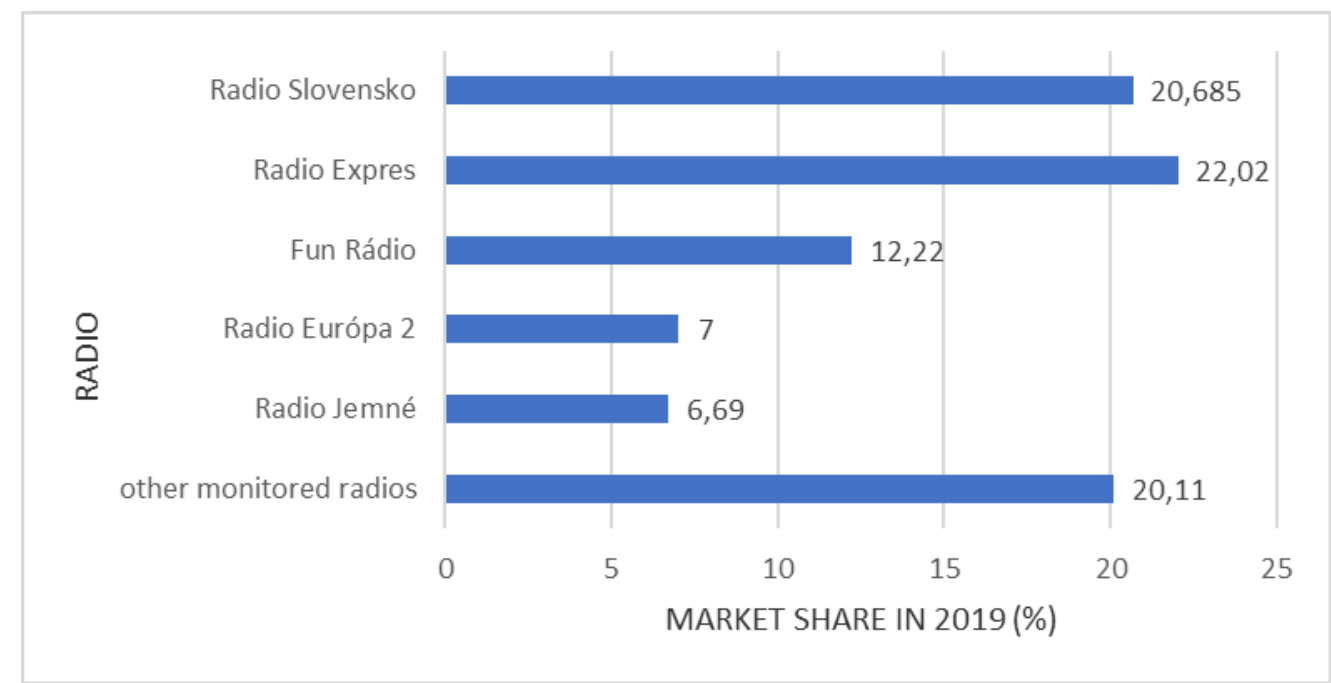

Fig. 7. Market share in 2019

Source: Processed form the results of the MML-TGI National Survey of MEDIAN SK

The growth of the media advertising market continued in 2019, when total advertising spending in Slovakia, according to Kantar, reached $€ 2,522,637,958$, which is an increase of $10.35 \%$ compared to the previous year ( $€$ $2,261,565,020) . € 104,326,654$ was invested in advertising space via radios in Slovakia, and a total of 2016 hours of advertising were broadcast in total.

In 2019, Radio Slovensko recorded an increase in the number of spots $(34,176)$, an increase in the total number of hours (212), as well as an increase in the value of advertising $(12,357,990)$, which is a record increase of $62.75 \%$ compared to previous years and other radios.

In 2019, Radio Expres broadcast fewer spots $(52,853)$ in a smaller number of hours $(318)$, for which it recorded an amount of $€ 29,752,591$, which is a decrease of $1.41 \%$ compared to the previous year.

Fun radio broadcast more commercials $(59,706)$, with more hours (359), while the value of its commercials in 2019 was $€ 24,247,053$, which is more than in the previous year.

Radio Europe 2 broadcast more commercials $(55,767)$ with more hours $(364)$ and its advertising space was valued at $€ 12,653,541$ this year, an increase of last year.

Radio Jemné broadcast fewer spots $(54,996)$ and less 367 hours of advertising and the value of advertising broadcasts was $€ 12,269,261$, which is a slight increase compared to last year. For more see Fig.8. 


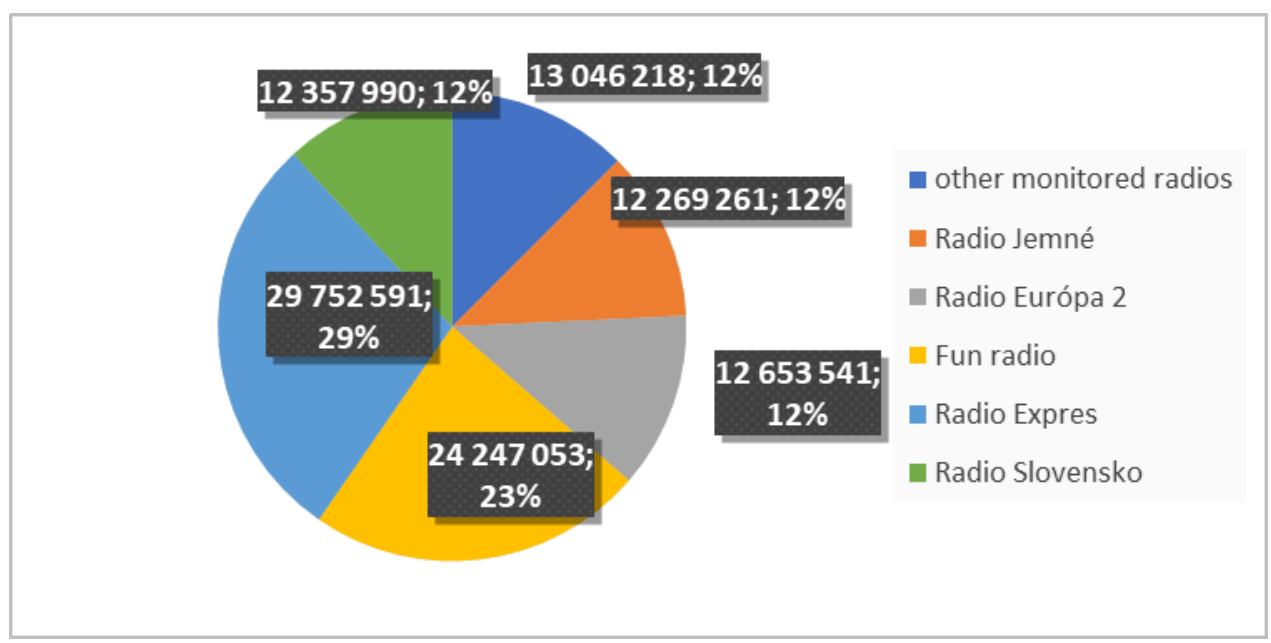

Fig .8. Share of radio volume in the year 2019

Source: Processed form the results of Kantar Slovakia Ltd.

Based on the analysis of listening to selected five radios in the Slovak Republic with nationwide coverage in the period from 2016 to 2019, the following conclusions can be stated within individual years. The most listened radio in Slovakia in 2016 remains Radio Expres with an average number of 867,669 listeners, followed by Radio Slovakia, Fun Radio, Radio Jemné and Radio Europe 2. Even in 2017, the most listened radio in Slovakia remains Radio Expres with an average number of 857,732 listeners, followed by Radio Slovakia, Fun Radio, Radio Jemné and Radio Europe 2. In 2018, Radio Expres remains the most listened-to radio station again, with an average number of 833,668 listeners, followed by Slovakia Radio, Fun Radio, and Radio Europe 2 and Radio Jemné exchanged fourth and fifth place. In 2019, in terms of listening, he copies the rankings from 2018: Radio Expres, Radio Slovakia, Fun Radio, Radio Europe 2, and Radio Jemné. The summary overview of listening for the monitored period 2016 to 2019 is shown using Fig. 9 and contains precise figures on the number of listeners in each year.

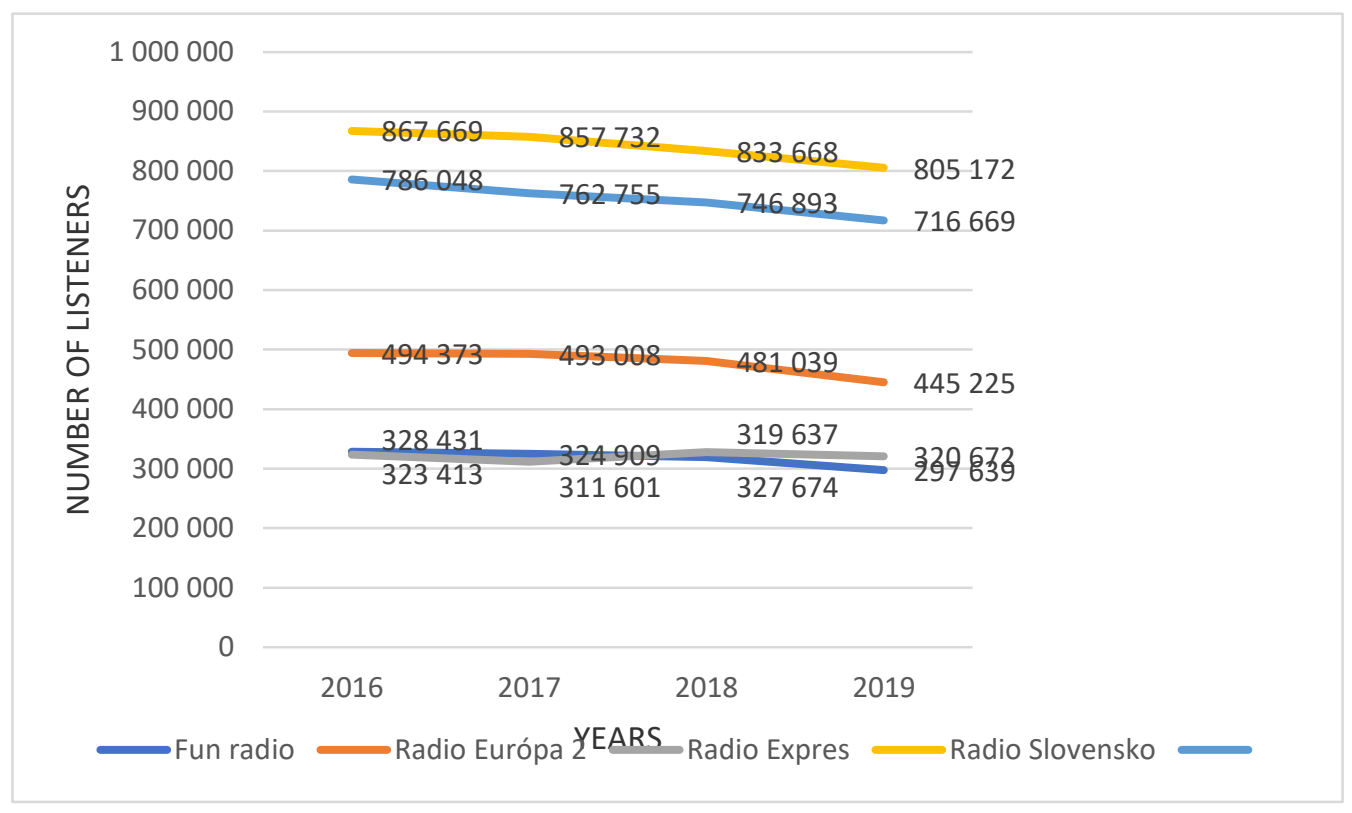

Fig. 9. Radio listening report 2016 - 2019 (in audience count)

Source: Processed form the results of the MML-TGI National Survey of MEDIAN SK 
Based on the analysis of the market share of selected five radios in the Slovak Republic with nationwide operations in the period from 2016 to 2019 , the following conclusions can be stated within individual years:

In 2016, all monitored radios recorded a decrease in the average number of listeners, but on the other hand, all monitored radios achieved a higher average annual market share. In 2017, all monitored radios achieved a slight decrease in the average number of listeners and, except for Fun radios, all radios also achieved a slight decrease in market share. Fun radio improved from an average market share of 12.45 in 2016 to $12.815 \%$ in 2017. In 2018, we also registered a slight decrease in the average number of listeners for most of the monitored radio stations, except for Fun Radio, which as the only radio reached a higher average number of listeners than in the previous year. In the case of the average market share, Radio Slovensko and Radio Európa 2 improved, while other radios declined. In 2019, we also recorded a slight decrease in the average number of listeners for all monitored radios. A summary overview of the development of the market share of individual radios for the monitored period from 2011 to 2019 is shown using Fig. 10

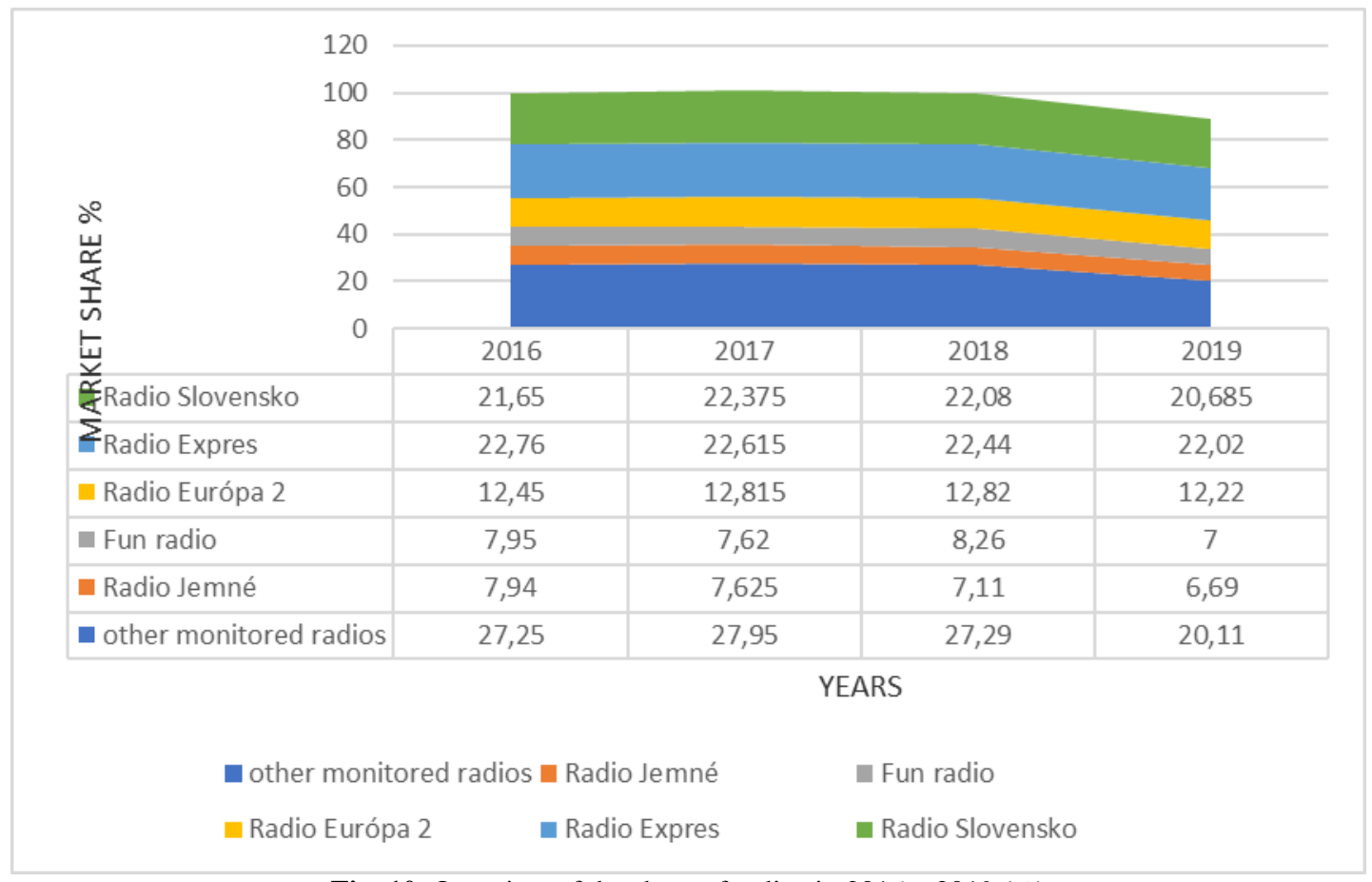

Fig. 10. Overview of the share of radios in $2016-2019(\%)$

Source: Processed form the results of the MML-TGI National Survey of MEDIAN SK

Based on the analysis of the development of the volume of advertising in selected nationwide radios in the years 2016 to 2019, the following conclusions can be stated:

The decrease in the volume of advertising can be observed in most radios also in 2016. The only radio Europe 2 in 2016 recorded a higher inflow in advertising than in the previous year. Slightly better in the case of investments in radio advertising was the year 2017, when 2 radios (Radio Expres, Radio Europe 2) out of 5 monitored recorded a higher volume of advertising than in the previous year. The year 2018 was economically successful for most radios, when they had a higher volume of advertising than in the previous year. In 2018, Radio Slovakia received the same amount for advertising as in the previous year. For a change, 2019 saw a decline in advertising revenue for most radios (Fine Radio, Fun Radio, Expres Radio), with Radio Europe 2 receiving the same amount 
of advertising revenue as the previous year. Radio Slovakia was the only radio in the year that received more advertising revenue than in 2018. A summary overview of the development of the volume of advertising of individual radios for the observed period from 2011 to 2019 is shown using Fig. 11.

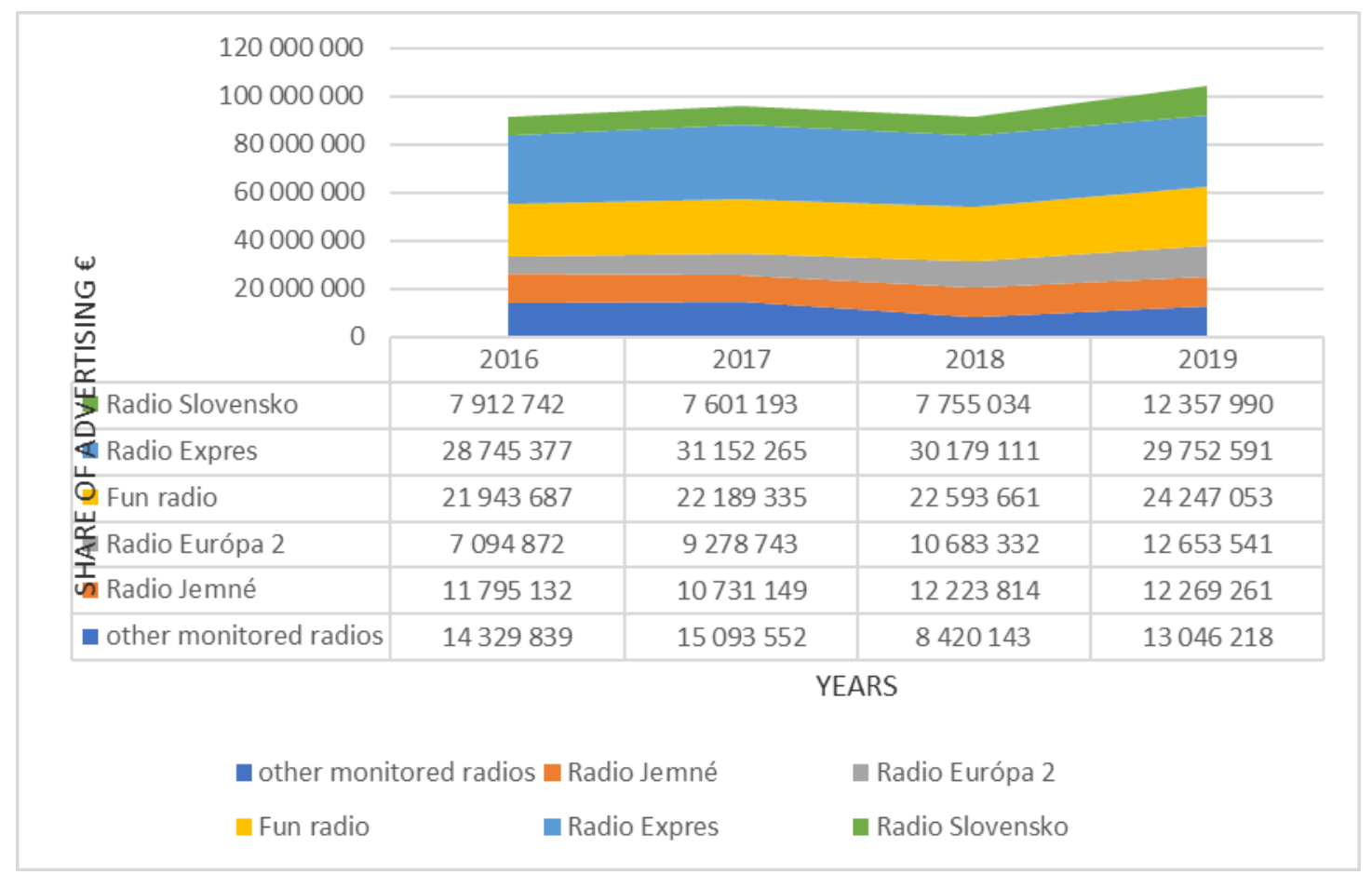

Fig. 11. Overview of the volume of radio advertising in $2016-2019(€)$

Source: Processed form the results of Kantar Slovakia Ltd.

\section{Conclusions}

Based on the analysis of the development tendencies of the market of selected five all-Slovak radios in the Slovak Republic for the observed period in the years 2016 to 2019, several development tendencies can be observed:

In the monitored period, the listening of most monitored radios continued to decline. For most of the monitored radios (Radio Jemné, Fun radio, Radio Európa 2, Radio Slovakia), listening was at the end of the analyzed period in 2019 lower than at the beginning in 2016. The only exception was Radio Expres. The radio market was stable in terms of radio ranking in 2016-2017 (Radio Expres, Radio Slovakia, Fun Radio, Radio Jemné, Radio Europe 2), while in 2018 the last 2 radios exchanged their rankings. The situation is even worse in the case of the market share of radios, where a decrease in market shares can be observed for all monitored radios, as they all achieved a lower market share in 2019 than at the beginning in 2016. In the case of the analysis of the volume of investments in radio advertising, no clear development trend can be observed. For the three monitored radios (Radio Slovakia, Radio Europe 2), the volume of acquired advertising at the end of the monitored period in 2019 was higher than in 2011, while for the remaining 3 radios the volume was lower or stagnated. It should be noted, however, that the increase and decrease in advertising volume was for individual radios in different periods. At the beginning of the period under review, after the economic recession and the decline in marketing investment after the financial and economic crisis, it is possible to observe an increase in the development of investment in radio advertising. It should be noted that the development of investment in radio advertising is influenced by 


\section{ENTREPRENEURSHIP AND SUSTAINABILITY ISSUES}

ISSN 2345-0282 (online) http://jssidoi.org/jesi/ 2020 Volume 2 Number 3 (September) http://doi.org/10.9770/IRD.2020.2.3(6)

several factors, with priority not only on the economic and market situation of investors, economic development, but also on the growing number of broadcasters and the media market.

Behind the decline in listening and market share, we can see the popularity of network media. As stated by Vavrečka (2016), especially the Internet and the tools derived from it create new possibilities in the field of communication tools, which in a way create a counterweight to the traditional mass means of communication.

Fortunately, in the case of radio, the situation is not as dramatic as in the case of declining sales and readability of the daily press, as confirmed by several studies at home and abroad. (Lincényi, Fabuš, 2017). The authors believe that the management of radio stations needs to constantly work on its development, the structure of broadcasting and adapt to the time that affects listeners, which can not only stop the decline in listening, but also have a chance to increase it.

\section{References}

BURTON, G., JIRÁK, J. 2001. Introduction to Media Studies. (Úvod do studia médií.) Praha: Barrister \& Principal, ISBN 978-80-8594767-6.

LINCÉNYI, M., FABUŠ, M. 2017. Economic trends of business actors on daily newspaper market: case of the Slovak Republic. Entrepreneurship and sustainability issues, 5(1), 91 - 104. https://doi.org/10.9770/jesi.2017.5.1(7)

FABUŠ, M., LINCÉNYI, M., 2018. Analysis of the development terms of the radio market in the Slovak republi. Entrepreneurship and sustainability issues, 6(2), 591 - 602, https://doi.org/10.9770/jesi.2018.6.2(9)

MEDIAN SK, MML-TGI. 2016. 1. + 2. vlna 2016, [19.03.2020]. https://www.radia.sk/pocuvanost/mml-tgi/vlny/2016-2

MEDIAN SK, MML-TGI. 2016. 3. + 4. vlna 2016 [19.03.2020]. https://www.radia.sk/pocuvanost/mml-tgi/vlny/2016-4

MEDIAN SK, MML-TGI. 2017. 1. + 2. vlna 2017 [19.03.2020]. https://www.radia.sk/pocuvanost/mml-tgi/vlny/2017-2

MEDIAN SK, MML-TGI. 2017. 3. + 4. vlna 2017 [19.03.2020]. https://www.radia.sk/pocuvanost/mml-tgi/vlny/2017-4

MEDIAN SK, MML-TGI. 2018. 1. + 2. vlna 2018 [19.03.2020]. https://www.radia.sk/pocuvanost/mml-tgi/vlny/2018-2

MEDIAN SK, MML-TGI. 2018. 3. + 4. vlna 2018 [19.03.2020]. https://www.radia.sk/pocuvanost/mml-tgi/vlny/2018-4

MEDIAN SK, MML-TGI. 2018. 1. + 2. vlna 2019 [19.03.2020]. https://www.radia.sk/pocuvanost/mml-tgi/vlny/2019-2

MEDIAN SK, MML-TGI. 2018. 3. + 4. vlna 2019 [19.03.2020]. https://www.radia.sk/pocuvanost/mml-tgi/vlny/2019-4

SVĚTLÍK, J. BULANDA, I. 2019. The shift of value types of the Czech population and its influence on the formation of creative advertising strategy. In Marketing Identity: Offline Is the New Online. Conference Proceedings from the International Scientific Conference. Trnava: Faculty of Mass Media Communication, University of SS. Cyril and

Methodius in Trnava, Slovakia, 2019, pp. 323-334.

VAVREČKA, V. 2016. Role a síla tradiční marketingové komunikace v kontextu trendů jejího vývoje (The role and strength of traditional marketing communication in the context of its development trends) In Média-moc-manipulácia. Bratislava: Paneurópska vysoká škola v Bratislave, 2016, pp. 455-478.

VENKATACHALAM, S., WONG, F., UYAR, E., WARD, S., AGGARWAL, A., 2015. Media Company Uses Analytics to Schedule Radio Advertisement Spots. Interfaces, 45(6), 485-500. https://doi.org/10.1287/inte.2015.0825 


\section{ENTREPRENEURSHIP AND SUSTAINABILITY ISSUES}

ISSN 2345-0282 (online) http://jssidoi.org/jesi/

2020 Volume 2 Number 3 (September)

http://doi.org/10.9770/IRD.2020.2.3(6)

\section{Acknowledgements}

The paper is the output of a scientific project IGA no. 3/2017 „Development of international business and international management in the conditions of globalization". (Funder: VSEMvs IGA VSEMvs, i.e. School of Economics and Management in Public Administration)

Marcel LINCÉNYI, PhD. in Media studies, obtained at Constantine the Philosopher University in Nitra, currently at Department of Maangement as associate professor, School of Economics and Management in Public Administration in Bratislava (VSEMvs), Slovakia.

ORCID ID: $\underline{\text { https://orcid.org/0000-0002-9076-026X }}$

Michal FABUS, PhD. in International Economics Relations, obtained at University of Economics in Bratislava, Vice-rector for Foreign Affairs, Head of Department of Economics and Finance, School of Economics and Management in Public Administration in Bratislava (VSEMvs), Slovakia.

ORCID ID: $\underline{\text { https://orcid.org/0000-0002-3792-179X }}$

Make your research more visible, join the Twitter account of INSIGHTS INTO REGIONAL DEVELOPMENT:

@IntoInsights

Copyright (C) 2020 by author(s) and VsI Entrepreneurship and Sustainability Center

This work is licensed under the Creative Commons Attribution International License (CC BY). http://creativecommons.org/licenses/by/4.0/

C) (i) Open Access 